\title{
Long-distance island hopping without dispersal stages: transportation across major zoogeographic barriers in a Southern Ocean isopod
}

\author{
Florian Leese • Shobhit Agrawal • Christoph Held
}

Received: 17 February 2010 /Revised: 25 April 2010 /Accepted: 26 April 2010 /Published online: 8 May 2010

(C) Springer-Verlag 2010

\begin{abstract}
Species integrity is maintained only if recurrent allelic exchange between subpopulations occurs by means of migrating specimens. Predictions of this gene flow on the basis of observed or assumed mobility of marine species have proven to be error-prone. Using one mitochondrial gene and seven microsatellite markers, we studied the genetic structure and gene flow in Septemserolis septemcarinata, a strictly benthic species lacking pelagic larvae and the ability to swim. Suitable shallow-water habitats around three remote islands (South Georgia, Bouvet, and Marion Island) are geographically disjunct, isolated by more than 2,000 km of uninhabitable deep sea (east-west) and also separated by the Polar Front (north-south), which serves as a strong demarcation line in many marine taxa. Although we did find genetic differentiation among the three island populations, our results also revealed that a scenario with recent gene flow explains our data best. A model assuming no gene flow after initial colonization of the islands performs significantly worse. The tests also favor an asymmetric gene flow pattern (west to east 》 east to west) thus mirroring the directionality of major ocean-
\end{abstract}

Electronic supplementary material The online version of this article (doi:10.1007/s00114-010-0674-y) contains supplementary material, which is available to authorized users.

F. Leese $(\bowtie)$

Department of Animal Ecology, Evolution and Biodiversity, Ruhr University Bochum,

Universitaetsstrasse 150,

44801 Bochum, Germany

e-mail: florian.leese@rub.de

S. Agrawal $\cdot$ C. Held

Department of Functional Ecology,

Alfred Wegener Institute for Polar and Marine Research, P.O. Box 120161, 27515 Bremerhaven, Germany ographic currents in the area. We conclude that rare longdistance dispersal rather than vicariance or human-mediated transport must be responsible for the observed patterns. As a mechanism, we propose passive rafting on floating substrata in the Antarctic Circumpolar Current. The results demonstrate that the effectiveness of a physical barrier is not solely a function of its physical parameters but strongly depends on how organisms interact with their environment.

Keywords Antarctic · Biogeography Gene flow Population genetics $\cdot$ Rafting $\cdot$ Serolidae

\section{Introduction}

Recent taxonomic work, the advent of molecular techniques, and improved sampling of regions such as tropical rainforests, the deep sea, and the Antarctic have made us increasingly aware of the fact that there may be significantly more species on this planet than previously assumed (Adams 2009; Brandt et al. 2007; Gutt et al. 2004). Even though there is still some uncertainty concerning the relative importance of different ways new species arise, a common denominator of most speciation concepts is that one previously contiguous gene pool gets divided into subsets, some of which may persist in isolation and eventually give rise to genetically independent novel species (Coyne and Orr 2004; Slatkin 1987). Gene flow on the other hand transports alleles from one place to another and has the potential to equalize genetic differences among populations (Bohonak 1999). Unlike mutations, genetic drift, and diversifying selection all of which will lead to differences among subpopulations of a species over time, effective gene flow merely rearranges already existing variation in space. Gene flow thus has the potential to even 
out genetic differences among populations very quickly if sufficiently high. If the objective is to understand the processes shaping genetic variation in space and ultimately also speciation itself, estimating migration is of utmost importance (Hellberg et al. 2002; Hudson et al. 1992; Neigel 1997; Slatkin 1987).

At the same time, migration is also one of the most difficult parameters to measure directly in the field: Except in some rare cases, marine invertebrates and fish species are too numerous, i.e., their census sizes too large and their body sizes too small to make direct observation and meaningful quantification of their dispersal feasible (Féral 2002). Furthermore, migration of a specimen as such does not manifest itself in the gene pool of the next generation until the migrant has reproduced successfully. Hence, an indirect a posteriori approach by measuring the spatial distribution of genetic variance and interpreting it as a result of past effective gene flow is often the only way to estimate the importance of migration on local or global scales (Féral 2002; Hellberg et al. 2002; Neigel 1997; Pawlowski et al. 2007). In general, highly mobile species, or species with pelagic larvae, tend to travel large distances more easily and are hence expected to be genetically more homogeneous than sessile species or species without dispersive life stages. Several empirical studies have shown, however, that often there is a striking discrepancy between dispersal potential and the actually realized dispersal, attributed, e.g., to differential adaptations to distinct environmental niches (Avise 2004), behavioral strategies (McQuinn 1997), or larval retention (Swearer et al. 1999) making predictions of genetic structure of such species prone to fail (e.g., Burg and Croxall 2004; Graves 1998; Jarman et al. 2002). The reverse situation is also happening: Passive transport on floating substrata such as wood, nuts, charcoal, algal mats, or even in the stomach of predators allows even relatively immobile species to surpass large distances (Nikula et al. 2010; Waters and Roy 2004; Thiel and Haye 2006 for review). Furthermore, anthropogenically mediated transport of specimens, e.g., attached to hulls of ships or on floating debris gains in importance although it is often unclear to which extent this actually influences the genetic structure of these species (e.g. Barnes 2002).

This study analyzes patterns of genetic connectivity and diversity among populations inhabiting remote Antarctic and sub-Antarctic islands (South Georgia, Bouvet, and Marion Island). These islands are ideal for a posteriori migration estimates in the marine realm because they are geographically isolated, only relatively few unsampled populations exist in between, and migration routes are theoretically predictable since ocean currents generally known (see also Nikula et al. 2010). Furthermore, anthropogenic influence is minimal in comparison to other ecosystems; thus, indirect migration estimates are less likely to be confounded, e.g., by transportation of specimens in ballast water of ships (but see Barnes 2002).

Gene flow among these three islands, if any, implies that considerable barriers to dispersal must be overcome: (1) the islands are physically isolated by more than $2,000 \mathrm{~km}$ of deep sea between them with no intermediary shallow water habitats (east-west, Fig. 1) and (2) the islands (South Georgia and Bouvet vs. Marion Island) are separated by the Polar Front (PF in Fig. 1) that serves a sharp demarcation line between the cold-adapted fauna of the Southern Ocean and that of other water bodies (north-south; Hunter and Halanych 2008; Krabbe et al. 2009; Thornhill et al. 2008; Wilson et al. 2009).

Although some fauna is known to be shared among the sub-Antarctic islands, some of this evidence is based on species for which the deep-water areas between the islands do not have a similarly strong isolating effect, either because they have pelagic larvae or show eurybathic distribution and hence are able to colonize isolated shallow water habitats through the deep sea (clades A and E in Krabbe et al. 2009; O'Hara 1998; Thornhill et al. 2008) or because they are capable of rafting (Nikula et al. 2010).

The benthic shallow-water isopod Septemserolis septemcarinata (Miers 1881) features none of these properties that may promote dispersal among the islands either via the shallow water or through the deep sea. It inhabits softbottom substrata (see Brandt 1991; Wägele 1994) and, like all peracarid crustaceans, this species possesses no pelagic larvae but instead broods its young in a brood pouch (marsupium) on the ventral side of the female. Neither juveniles nor adults of $S$. septemcarinata can swim for any length of time, and the species is only known to occur in waters shallower than $500 \mathrm{~m}$.

Unlike species with pelagic larvae or drifting life stages for which dispersal with the strong eastward flow of the Antarctic Circumpolar Current (ACC, Fig. 1) is regarded as a possible means to maintain genetic connectivity among remote populations (Fraser et al. 2009), the stretches of deep sea separating the islands ( $>2,000 \mathrm{~km}$ each, see Fig. 1) most likely represent a significant barrier to dispersal for this species.

In this paper, we apply an a posteriori approach to assess the genetic connectivity of $S$. septemcarinata among the highly disjunct (east-west) islands and even across the Polar Front (north-south) using cytochrome c oxidase subunit I (COI) and microsatellites as two different molecular marker systems (see discussion in Held and Leese 2007). In view of the recent discovery of strong spatial structuring and even reproductively isolated sibling species within the same family (Serolidae) on the Antarctic and South American shelves under conditions that provide less physical isolation (Held 2001; Leese and Held 2008; 
Fig. 1 Upper graph: Sampling sites of $S$. septemcarinata in the Southern Ocean ( $S G$ South Georgia, BI Bouvet Island) and the southern Indian Ocean (MI Marion Island) along a transect (red line). Polar Front ( $P F$, dashed line) and Antarctic Circumpolar Current (ACC, black arrows) schematically according to Orsi et al. (1995) and Stewart (2007). Arrowheads indicate the direction of the ACC. Middle figure: A bathymetric cross section with depth and temperature profiles between South Georgia, Bouvet, and Marion Island based on the data summarized by Gouretski and Koltermann (2004). The cross section highlights the absence of intermediate shallow benthic habitats available for $S$. septemcarinata between the three remote islands. Lower graph: Evidence for stark temperature difference between the sea surface temperatures (SSTS) around the islands within the PF (SG and BI; $0-1{ }^{\circ} \mathrm{C}$ ) and outside it (MI; 5- ${ }^{\circ} \mathrm{C}$ )

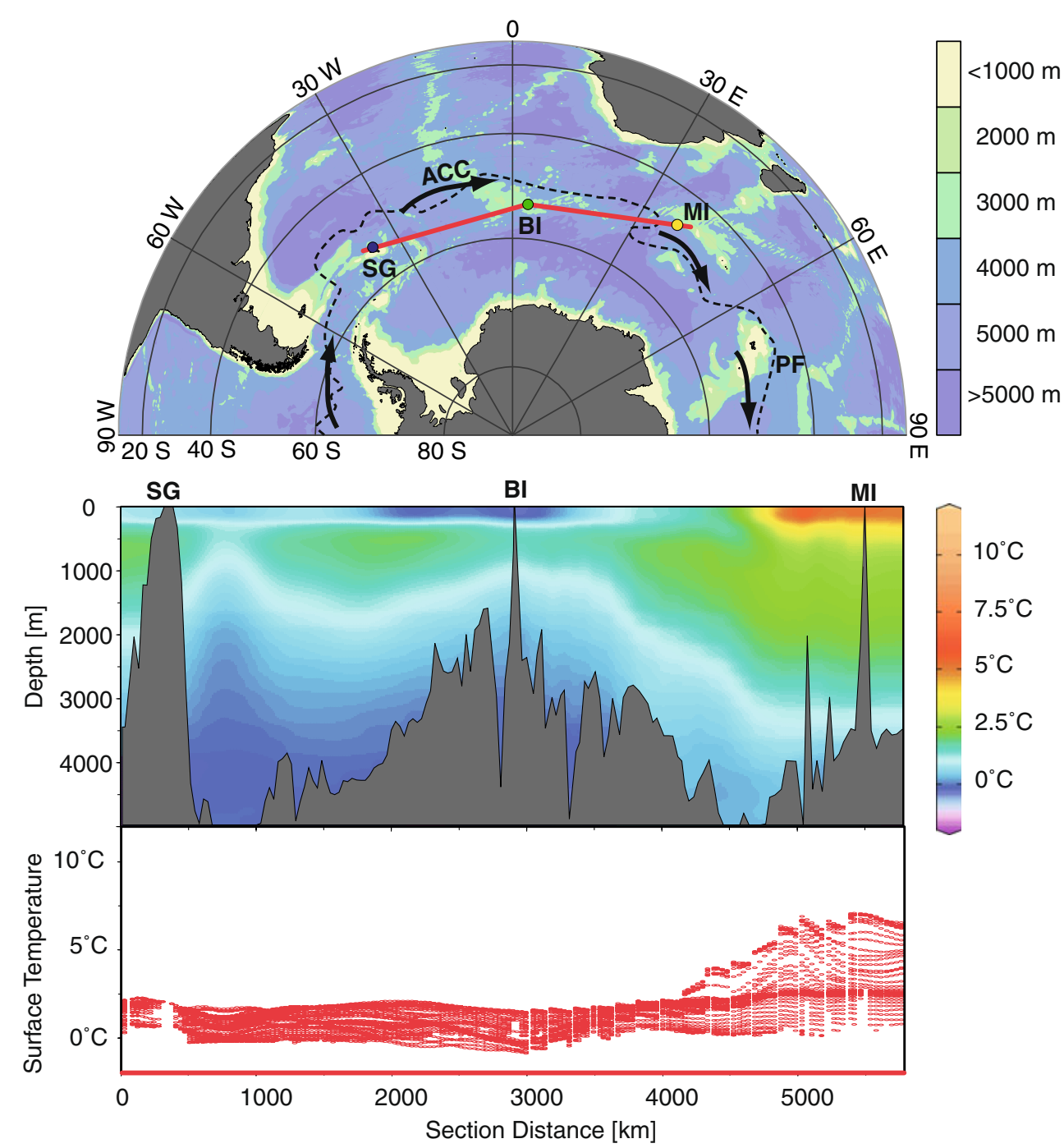

Leese et al. 2008a, b), we also test whether nominal $S$. septemcarinata is indeed a single interbreeding species maintaining its integrity across major barriers.

\section{Materials and methods}

Taxon sampling

Specimens were collected by bottom trawling on soft sediments during the ICEFISH 2004 expedition from shallow waters around South Georgia and Bouvet Island. Specimens from Marion Island were sampled on the MIOSIV expedition using a 1.5-m Agassiz' trawl and a metal stone dredge (Table 1; Fig. 1). The samples of $S$. septemcarinata were obtained from all suitable trawling grounds around Bouvet and Marion Island with no strong geographic bias, whereas the South Georgia samples originate predominantly from the Grytviken area to the west of the island; trawling in other areas yielded no additional material. Animals were immediately sorted on deck and preserved in prechilled $96 \%$ ethanol. Specimens were kept at $4^{\circ} \mathrm{C}$ for the first months to guarantee adequate tissue preservation and maximum yield for subsequent DNA extraction.

Microsatellite analyses were performed for 95 specimens (56 from Bouvet Island, 34 from South Georgia, and all five specimens found from Marion Island). Mitochondrial diversity was assessed for subsets of the populations from Bouvet Island and South Georgia and all specimens from Marion Island (Table 1; see Fig. 1 for location of islands).

DNA extraction, PCR, sequencing/genotyping

Total DNA from specimens from Bouvet Island and South Georgia was extracted from muscle tissue of three to four walking legs using the Qiagen DNeasy Mini Kit according to the standard tissue protocol using only $50 \mu \mathrm{l}$ of elution buffer to increase concentration. DNA of specimens from Marion Island was extracted from muscle tissue of one leg only using the DNeasy Micro Kit (Qiagen). 
Table 1 Sampling site details and cruise information for the populations of $S$. septemcarinata analyzed

\begin{tabular}{|c|c|c|c|c|c|}
\hline Island (age, size) & Latitude/longitude & Depth $(\mathrm{m})$ & Cruise & $N_{\text {MSAT }}$ & $N_{\text {mtDNA }}$ \\
\hline South Georgia $\left(>100 \mathrm{Ma}, 1,700 \mathrm{~km}^{2}\right)$ & $54^{\circ} 01^{\prime} \mathrm{S}, 36^{\circ} 49^{\prime} \mathrm{W}$ & $<200$ & ICEFISH 2004 & 34 & 33 \\
\hline Bouvet Island (1 Ma, $\left.50 \quad \mathrm{~km}^{2}\right)$ & $54^{\circ} 27^{\prime} \mathrm{S}, 3^{\circ} 17^{\prime} \mathrm{E}$ & $<200$ & ICEFISH 2004 & 56 & 21 \\
\hline Marion Island (0.25-0.45 Ma, $\left.290 \mathrm{~km}^{2}\right)$ & $46^{\circ} 53^{\prime} \mathrm{S}, 37^{\circ} 44^{\prime} \mathrm{E}$ & $<200$ & MIOS-IV & 5 & 5 \\
\hline
\end{tabular}

In parentheses, the estimated geological age (in million years, Ma) and the approximate size in square kilometers are listed. The number of individuals analyzed for microsatellites $\left(N_{\text {Msat }}\right)$ and the mitochondrial cytochrome oxidase I $\left(N_{\mathrm{mtDNA}}\right)$ are given

Cytochrome $c$ oxidase subunit I The universal primers HCO2198 and LCO1490 (Folmer et al. 1994) were used to amplify a fragment of the COI for a subset of 59 specimens (Table 1). Reactions were carried out in $25 \mu$ l volumes with $1 \times$ HotMaster reaction buffer, $0.2 \mathrm{mM}$ dNTPs, $0.5 \mu \mathrm{M}$ of each primer, and $0.025 \mathrm{U} / \mu \mathrm{l}$ Hotmaster Taq. Reaction conditions were initial denaturation for $2 \mathrm{~min}$ at $94^{\circ} \mathrm{C}$ followed by 36 cycles of $20 \mathrm{~s}$ at $94^{\circ}, 15 \mathrm{~s}$ at $46^{\circ} \mathrm{C}$, and $80 \mathrm{~s}$ at $65^{\circ} \mathrm{C}$ plus a final elongation step of $5 \mathrm{~min}$ at $65^{\circ} \mathrm{C}$. PCR products were purified using Qiagen Qiaquick PCR purification or MinElute kit. Cycle sequencing using $1 \mu \mathrm{M} \mathrm{HCO} / \mathrm{LCO}$ primers was conducted in $10 \mu \mathrm{l}$ reaction volumes using $1 \mu \mathrm{l}$ of the purified template DNA and the BigDye Termiator Kit 3.1 (Applied Biosystems) according to the recommendations. Reactions were purified according to the "modified protocol" of the Qiagen DyEx Kit. Sequencing was conducted on an ABI 3130xl sequencer.

Microsatellites Eight polymorphic microsatellite loci developed for S. septemcarinata (Leese et al. 2008b) were applied to assess intraspecific genetic polymorphisms for all specimens from Bouvet Island and South Georgia and seven (except for Sse14) for Marion Island. For standard $15 \mu 1$ reactions with one labeled and one unlabeled primer and the respective thermal cycling program, see Leese et al. (2008b). Fragment analysis was conducted on an ABI 3130xl sequencer. Allele length scoring was performed using the software GENEMAPPER 4.0 (Applied Biosystems). To minimize scoring errors, up to four independent reactions were performed for a subset of samples to confirm genotypes.

Data analysis

\section{Cytochrome oxidase I}

Assembly of forward and reverse strands and editing was performed using the software SEQMAN (Dnastar, Lasergene). Sequence alignment was trivial and performed using CLusTALW as implemented in BIOEDIT version 7.09 (see Electronic supplement 1 for program details). Sequence variation was analyzed using MEGA version 4.0. A statistical parsimony network based on COI haplotype data was calculated using TCS version 1.21. Population differentiation was estimated by conventional F-statistics based on haplotype frequencies using ARLEQUIN version 3.11. Significance of differentiation estimates was assessed by an exact test as implemented in ARLEQUIN. Parameter settings were burnin 10,000, Markov Chain Monte Carlo (MCMC) steps 100,000 .

\section{Microsatellites}

Raw data were checked and corrected for genotyping errors using the software MICRO-CHECKER version 2.2.3 and DROPOUT version 1.3. In addition, MICRO-CHECKER was used to test for the presence of null alleles in populations. Allele scoring was performed independently twice to maximize the reliability of the data. Corrected genotype tables were converted to specific software formats using MSTOOLKIT version 3.1, CONVERT version 1.3.1, and FABOX version 1.3. Bonferroni-corrected significance was assessed using a permutation test with 10,000 permutations. Tests for Hardy-Weinberg equilibrium (HWE) and linkage disequilibrium (LD) were performed using GENEPOP version 4.0.6.

Population differentiation was assessed by calculating a coancestry coefficient similar to Weir and Cockerham's $F_{\text {ST }}$ estimate $\theta$ (Weir and Cockerham 1984). Calculations were performed using the software GENEPOP version 4.0.6. Significance of differentiation was assessed by an exact test ( $G$ test; parameters 10,000 burnin, 50 batches with 10,000 MCMC steps each). $F_{\mathrm{ST}}$ estimates were standardized in an ANOVA framework as outlined by Meirmans (2006) using the program RECODEDATA and subsequently GENEPOP to calculate the maximum value possible for $F_{\mathrm{ST}}$.

Furthermore, we applied a Bayesian multilocus-based clustering method implemented in the program STRUCTURE version 2.2.2, to simultaneously infer population structure and assign individuals to populations. Assuming HWE and no or only weak linkage disequilibrium within subpopulations, STRUCTURE assigns individuals in the data set probabilistically to populations, or jointly to two or more populations if genotypic data of individuals indicate that they are admixed. For the $S$. septemcarinata data set, the most likely number of populations was inferred without prior information on geographic origin of individuals using 
STRUCTURE. The number of MCMC steps needed to reach convergence was first estimated by comparing run lengths between 10,000 and 2,000,000 steps. Convergence was reached in general within 10,000 steps. Therefore, for these parameter sets, five independent runs with a burn-in of 10,000 and subsequent 50,000 MCMC steps were performed with and without assuming population admixture and with and without correlated allele frequencies. The number of clusters $(K)$ to infer was set from $K=1$ to $K=4$ to allow for detection of potential cryptic subpopulations. Alpha was inferred from the data for each population separately in the admixture mode. All five independent runs were analyzed in CLUMPP, version 1.1.1, in order to compute a consensus matrix from all five matrices. Both the individual membership coefficient matrix and averaged population membership matrix (Q-matrices) were visualized using DISTRUCT, version 1.1.

The absence/presence and direction of the gene flow between the three island populations was inferred based on the log Bayes factor (LBF) as per the model ranking method demonstrated in Beerli and Palczewski (2010) using the coalescent-based MCMC method implemented in the program MIGRATE-N, version 3.1.3. Using microsatellite data, the harmonic mean-based LBFs (Beerli and Palczewski 2010) were estimated to compare the null model of no migration $\left(M_{0}\right)$ to the models of unidirectional migration from west to east with exclusive migration to adjacent islands (South Georgia to Bouvet Island to Marion Island; $M_{1}$ ), migration in the same direction but also including migration to Marion Island from South Georgia $\left(M_{2}\right)$, and finally in the opposite direction from Marion Island to South Georgia and Bouvet Island $\left(M_{3}\right)$. Runs were carried out multiple times with varying parameter settings to achieve convergence, and the final MCMC parameters were four long chains with 100,000 recorded steps and a 100 -step increment with a burn in of 10,000 . The total

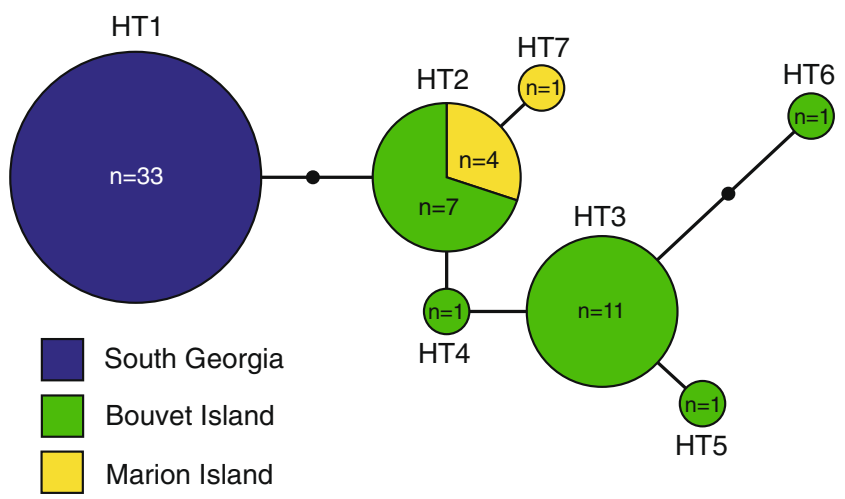

Fig. 2 Statistical parsimony network of $n=59$ cytochrome oxidase I sequences in seven haplotypes (HT1-HT7) from S. septemcarinata (TCS, 95\% parsimony connection limit). The circle diameters correspond to the number of specimens that share a particular haplotype. Black dots represent hypothetical, unsampled haplotypes number of sampled parameter values was ten million with a uniform distribution for theta $(0.0-0.1)$ and $M(0.0-1,000)$.

For all genetic analysis methods, see Electronic supplement 1 for details and program citations.

\section{Results}

Cytochrome oxidase I

Base-pair frequencies of the 551-bp fragment of the partial COI gene were $A=22.9 \%, C=18.9 \%, G=21.9 \%$, and $T=36.3 \%$, respectively. Eight positions were variable, four being parsimony-informative and four singleton sites (i.e., autapomorphies). All substitutions were silent mutations. The $n=33$ specimens from South Georgia represented one single haplotype (HT1). Haplotype 2 (HT2) was shared among specimens from Bouvet $(n=7)$ and Marion Island $(n=4)$. Haplotype 3 (HT3) was only reported for specimens from Bouvet Island. Haplotypes 4-6 (HT4-6) were found in single specimens from Bouvet, and haplotype 7 (HT7) was found in one specimen from Marion Island (Fig. 2; Table 2). Haplotype sequences were deposited in GenBank (EU597351-EU597357).

Genetic structure and diversity The average pairwise distances between groups were low (Table 3), yet the population from South Georgia was significantly different from those from the two other islands. The maximum uncorrected pairwise genetic distance was between HT1 and HT6 (1.1\%). Some haplotypes were shared between specimens sampled around Bouvet and Marion Island (Fig. 2). No bimodal distribution of genetic distances ("barcoding gap") was observed. As a consequence based on the COI data, we consider the different populations to belong to one species rather than to several cryptic species.

Nucleotide diversity and pairwise differences $(\pi)$ were zero for the populations of South Georgia (i.e., invariant), higher for Marion Island (0.0007/0.400) and highest for the population from the smallest island Bouvet (0.0023/1.248). This is unexpected at first with regards to the geological age and size of the islands (see Table 1).

\section{Microsatellites}

Microsatellites were polymorphic in all three populations (Table 4). The number of alleles per microsatellite locus for all specimens screened ranged from $N_{\mathrm{A}}=2(\mathrm{Sse} 05)$ to $N_{\mathrm{A}}=$ 25 (Sse10; see Electronic supplement 2 for frequency distributions of alleles). Observed heterozygosity $\left(H_{\mathrm{o}}\right)$ ranged from 0.059 (Sse05, South Georgia population) to 0.911 (Sse10, Bouvet Island population). No significant 
Table 2 Frequency and geographic origin of the mitochondrial cytochrome c oxidase subunit I haplotypes for the populations of S. septemcarinata from South Georgia, Bouvet, and Marion Island

\begin{tabular}{lllll}
\hline Haplotype & South Georgia & Bouvet Island & Marion Island & GenBank accession number \\
\hline HT1 & 33 & 0 & 0 & EU597351 \\
HT2 & 0 & 7 & 4 & EU597352 \\
HT3 & 0 & 11 & 0 & EU597353 \\
HT4 & 0 & 1 & 0 & EU597354 \\
HT5 & 0 & 1 & 0 & EU597355 \\
HT6 & 0 & 1 & 0 & EU597356 \\
HT7 & 0 & 0 & 1 & EU597357 \\
\hline
\end{tabular}

deviations from HWE were found for the populations from Bouvet or Marion Island. A significant heterozygosity deficiency was reported for locus Sse14 for the population from South Georgia. Analyses with MICRO-CHECKER indicated that this may be best explained due to the presence of null alleles at this locus. When removing locus Sse14, global tests for deviations from HWE did not detect a significant heterozygosity deficiency (Table 4). Significant global LD after Bonferroni correction for multiple testing was observed for locus pair Sse14 and Sse15 only. As locus Sse14 also showed a significantly inflated homozygosity and could not be genotyped for the five specimens from Marion Island, this locus was excluded from population genetic parameter inference in this study.

Genetic structure and diversity Genetic polymorphisms show a strong geographical association, with differences in allele types and frequencies among the islands (see Electronic supplement 2). Population differentiation estimates based on Weir and Cockerham's $F_{\mathrm{ST}}$ estimate (Weir and Cockerham 1984) revealed significant population differentiation between all pairs of populations (Table 5). Nonstandardized $F_{\mathrm{ST}}$ estimates were similarly high between population pairs South Georgia/Bouvet Island and South Georgia/Marion but lower for Bouvet/Marion Island, indicating that gene flow between Bouvet and Marion Island is somewhat higher. Calculations of the standardized $F_{\text {ST }}^{\prime}$ show that nonstandardized $F_{\mathrm{ST}}$ estimates tend to underestimate differentiation. The magnitudes of the pairwise $F_{\text {ST }}^{\prime}$ suggest that gene flow between populations is very restricted.
Results of the Bayesian cluster analyses of STRUCTURE reported the highest likelihood of the data when using information on population origin (i.e., $K=3$ ) as a prior: $\mathrm{Ln}$ $\operatorname{Pr}(D \mid K)_{K=3}=-2,322.5$. All individuals were assigned correctly to their population of origin with small but distinct genotypic admixture proportions (Fig. 3). When searching for the $K$ with the highest likelihood without prior information on the geographic origin of individuals, results depended on the model assumptions. Under an admixture model, STRUCTURE reported the highest likelihood for $K=3$ : $\operatorname{Ln} \operatorname{Pr}(D \mid K)_{K=3}=-2,350.8$. The three clusters inferred corresponded to the three islands sampled (Fig. 3). However, populations from Bouvet and Marion Island also contained specimens with shared genotype proportions that indicate genetic admixture. Furthermore, one specimen from Bouvet Island had a genotype similar to the dominant genotype of the South Georgia population and one individual with almost equal proportions of a typical Bouvet and a typical Marion Island genotype. If no admixture was assumed in the model, STRUCTURE reported the highest likelihood for $K=2$. $\operatorname{Ln} \operatorname{Pr}(D \mid K)_{K=2}=-2,369.4$. The individuals from South Georgia had high proportions for cluster one and individuals from Bouvet and Marion Islands to cluster two, indicating that populations from these islands share a common history. Interestingly, two of the five specimens from Marion Island had high admixture proportions $q_{\mathrm{n}}$ of cluster one (South Georgia): $q_{1}=0.32$ and 0.45 , respectively. No individual with a higher admixture proportion than 0.1 was found in the Bouvet Island population (Q-matrix plots not shown).

Table 3 Differentiation estimates based on a 551-bp fragment of the mitochondrial cytochrome c oxidase subunit I gene

\begin{tabular}{llll}
\hline & South Georgia & Bouvet Island & Marion Island (\%) \\
\hline South Georgia & $0 \%$ & $0.6 \%$ & 0.4 \\
Bouvet Island & $0.854(P<0.001)$ & $0.2 \%$ & 0.3 \\
Marion Island & $0.980(P<0.001)$ & $0.400(P=0.078)$ & 0.1 \\
\hline
\end{tabular}

Pairwise $F_{\mathrm{ST}}$ estimates with respective $P$ values (lower diagonal) and average uncorrected pairwise genetic distances within (diagonal) and between (upper diagonal) populations of $S$. septemcarinata 
Table 4 Total number of specimens scored for each population and locus $\left(N_{\mathrm{S}}\right)$, number of different alleles $\left(N_{\mathrm{A}}\right)$, inbreeding coefficient $\left(F_{\mathrm{IS}}\right)$, observed heterozygosity $\left(H_{\mathrm{O}}\right)$, expected heterozygosity $\left(H_{\mathrm{e}}\right)$, and probability (unbiased estimate of type I error) for HardyWeinberg departure proportions $\left(P_{\mathrm{HW}}\right)$

\begin{tabular}{|c|c|c|c|}
\hline & South Georgia & Bouvet Island & Marion Island \\
\hline \multicolumn{4}{|l|}{ Sse04 } \\
\hline$N_{\mathrm{S}}$ & 34 & 56 & 5 \\
\hline$N_{\mathrm{A}}$ & 10 & 13 & 2 \\
\hline$F_{\mathrm{IS}}$ & 0.113 & 0.077 & -0.333 \\
\hline$H_{\mathrm{o}}$ & 0.588 & 0.750 & 0.600 \\
\hline$H_{\mathrm{e}}$ & 0.662 & 0.812 & 0.467 \\
\hline$P_{\mathrm{HW}}$ & 0.105 & 0.353 & 1.000 \\
\hline \multicolumn{4}{|l|}{ Sse05 } \\
\hline$N_{\mathrm{S}}$ & 34 & 53 & 5 \\
\hline$N_{\mathrm{A}}$ & 2 & 2 & 3 \\
\hline$F_{\text {IS }}$ & -0.015 & 0.000 & -0.067 \\
\hline$H_{\mathrm{o}}$ & 0.059 & 0.245 & 0.400 \\
\hline$H_{\mathrm{e}}$ & 0.058 & 0.245 & 0.378 \\
\hline$P_{\mathrm{HW}}$ & 1.000 & 1.000 & 1.000 \\
\hline \multicolumn{4}{|l|}{ Sse 07} \\
\hline$N_{\mathrm{S}}$ & 34 & 56 & 5 \\
\hline$N_{\mathrm{A}}$ & 2 & 4 & 2 \\
\hline$F_{\mathrm{IS}}$ & -0.060 & 0.036 & -0.600 \\
\hline$H_{\mathrm{o}}$ & 0.471 & 0.429 & 0.800 \\
\hline$H_{\mathrm{e}}$ & 0.444 & 0.444 & 0.533 \\
\hline$P_{\mathrm{HW}}$ & 1.000 & 0.613 & 0.428 \\
\hline \multicolumn{4}{|l|}{ Sse 08} \\
\hline$N_{\mathrm{S}}$ & 30 & 54 & 5 \\
\hline$N_{\mathrm{A}}$ & 7 & 13 & 6 \\
\hline$F_{\text {IS }}$ & -0.072 & 0.093 & 0.314 \\
\hline$H_{\mathrm{o}}$ & 0.767 & 0.815 & 0.600 \\
\hline$H_{\mathrm{e}}$ & 0.716 & 0.857 & 0.844 \\
\hline$P_{\mathrm{HW}}$ & 0.114 & 0.990 & 0.162 \\
\hline \multicolumn{4}{|l|}{ Sse10 } \\
\hline$N_{\mathrm{S}}$ & 34 & 56 & 5 \\
\hline$N_{\mathrm{A}}$ & 15 & 18 & 7 \\
\hline$F_{\text {IS }}$ & 0.186 & 0.018 & 0.135 \\
\hline$H_{\mathrm{o}}$ & 0.706 & 0.911 & 0.911 \\
\hline$H_{\mathrm{e}}$ & 0.864 & 0.927 & 0.800 \\
\hline$P_{\mathrm{HW}}$ & 0.045 & 0.553 & 0.491 \\
\hline \multicolumn{4}{|l|}{ Sse13 } \\
\hline$N_{\mathrm{S}}$ & 34 & 55 & 5 \\
\hline$N_{\mathrm{A}}$ & 13 & 11 & 7 \\
\hline$F_{\text {IS }}$ & -0.046 & -0.007 & -0.081 \\
\hline$H_{\mathrm{o}}$ & 0.882 & 0.836 & 1.000 \\
\hline$H_{\mathrm{e}}$ & 0.844 & 0.831 & 0.933 \\
\hline$P_{\mathrm{HW}}$ & 0.969 & 0.719 & 1.000 \\
\hline \multicolumn{4}{|l|}{ Sse14 } \\
\hline$N_{\mathrm{S}}$ & 23 & 56 & 0 \\
\hline$N_{\mathrm{A}}$ & 8 & 13 & - \\
\hline
\end{tabular}

(continued)

\begin{tabular}{lccc}
\hline & South Georgia & Bouvet Island & Marion Island \\
\hline$F_{\mathrm{IS}}$ & 0.734 & 0.064 & - \\
$H_{\mathrm{o}}$ & 0.192 & 0.804 & - \\
$H_{\mathrm{e}}$ & 0.713 & 0.858 & - \\
$P_{\mathrm{HW}}$ & 0.000 & 0.272 & - \\
Sse15 & & & 5 \\
$N_{\mathrm{S}}$ & 34 & 56 & 8 \\
$N_{\mathrm{A}}$ & 13 & 15 & -0.056 \\
$F_{\mathrm{IS}}$ & 0.1429 & 0.055 & 1.000 \\
$H_{\mathrm{o}}$ & 0.706 & 0.821 & 0.956 \\
$H_{\mathrm{e}}$ & 0.822 & 0.869 & 1.000 \\
$P_{\mathrm{HW}}$ & 0.057 & 0.202 & - \\
Total & & & - \\
Mean $H_{\mathrm{E}}$ & 0.640 & 0.730 & - \\
Mean $H_{\mathrm{O}}$ & 0.546 & 0.701 & 0.717 \\
$P_{\mathrm{HW}}$ & 0.000 & 0.064 & 0.943 \\
Excl. Sse14 & & & \\
Mean $H_{\mathrm{E}}$ & 0.630 & 0.712 & 0.687 \\
Mean $H_{\mathrm{O}}$ & 0.597 & 0.870 & \\
$P_{\mathrm{HW}}$ & 0.103 & & \\
\hline
\end{tabular}

The mean $H_{\mathrm{O}}$ and $H_{\mathrm{E}}$ for all microsatellites and the data set and their respective overall $P_{\mathrm{HW}}$ are listed at the end of the table. Due to the very limited amount of DNA, locus Sse14 was not amplified for the population from Marion Island

The results of the MIGRATE-N analyses (Table 6) indicate clearly that all models of gene flow/migration $\left(\mathrm{M}_{1}\right.$, $\mathrm{M}_{2}, \mathrm{M}_{3}$, ranks $\left.1,2,3\right)$ are more likely than the null hypothesis of no gene flow $\left(\mathrm{M}_{0}\right.$, rank 4). Although a westto-east migration model with exclusive gene flow between adjacent islands is ranked below an east-to-west migration model, congruent to our hypotheses of gene flow in the direction of the Antarctic Circumpolar Current, the most highly ranked model $\left(M_{2}\right)$ is the one which shows a westward migration pattern which includes migration not

Table 5 Differentiation estimates based on seven microsatellite markers

\begin{tabular}{llll}
\hline & South Georgia & Bouvet Island & Marion Island \\
\hline South Georgia & - & $0.139(0.325)$ & $0.141(0.339)$ \\
Bouvet Island & 0.427 & - & $0.088(0.285)$ \\
Marion Island & 0.420 & 0.311 & - \\
\hline
\end{tabular}

Upper diagonal: pairwise $F_{\mathrm{ST}}$ estimates and maximum possible $F_{\mathrm{ST}}$ estimates between island populations of $S$. septemcarinata. Lower diagonal: standardized pairwise $F_{\text {ST }}^{\prime}$. All pairwise differentiation estimates are significant at $P<0.001$ 

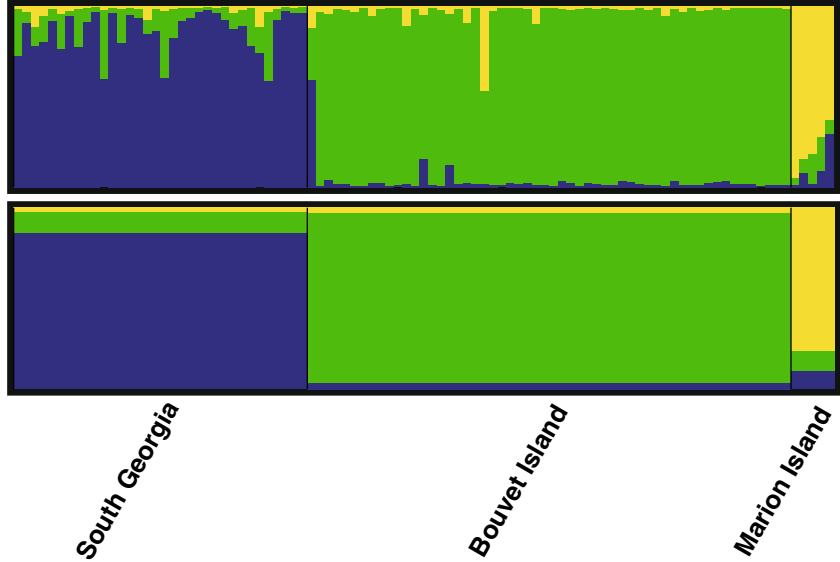

Fig. 3 Results of cluster analyses performed with STRUCTURE with the highest log likelihood without prior information on population origin. The upper graph displays the consensus membership coefficients matrices (Q-matrices) for 95 individuals from three populations of $S$. septemcarinata (South Georgia $=$ blue, Bouvet Island $=$ green, Marion Island $=$ yellow) using seven microsatellite markers. The genotype of each individual is represented by a single bar, where the proportion of the color refers to the probability of assignment to one of the three populations. The lower graph displays the averaged population membership matrix

only between the adjacent islands of South Georgia and Bouvet Island, and Bouvet and Marion Island but also for the two distant islands of South Georgia and Marion Island.

Intrapopulation gene diversity in terms of expected heterozygosity $\left(H_{\mathrm{E}}\right)$ was higher for populations from the smaller and younger islands of Bouvet and Marion $\left(H_{\mathrm{E}}=\right.$ 0.712 and 0.717 , respectively) compared to the population from South Georgia (0.630). As $H_{\mathrm{E}}$ is not sensitive to sample size and only the loci without evidence for null alleles were included, this can be regarded a distinguishing feature of the three different populations (South Georgia vs. Marion and Bouvet Island). However, results were statistically significant for the comparison of South Georgia vs. Bouvet Island only due to the small sample size for Marion Island (Wilcoxon signed rank test: $W=$ 26.00, $P=0.031$ ).

\section{Discussion}

One unexpectedly mobile species

The maximum uncorrected pairwise genetic distances between the different S. septemcarinata COI haplotypes were $1.1 \%$, which fits well in the range of values expected for a single interbreeding species. The mitochondrial haplotypes shared among specimens from Bouvet and Marion Islands further support this. The South Georgia population is characterized by a single COI haplotype which differs only in two positions from the most similar haplotype found on the other two islands. At present, it cannot be excluded that genealogical relatedness among the sampled individuals from the sampled area near South Georgia may have artifactually deflated the genetic variability in particular for mitochondrial markers, thus concealing a possible overlap of COI genetic variance among South Georgia and the other populations in this study. In any case, the differentiation is small (two mutations) and well within the expected variance within an interbreeding species. The species integrity of a rather immobile benthic brooder without swimming life stages across major barriers for dispersal is highly remarkable in view of recent findings of sibling isopod species under conditions which provide less physical separation elsewhere (Held 2003; Held and Wägele 2005; Raupach and Wägele 2006; Raupach et al. 2007). Studies in other isopods from the Antarctic and subAntarctic based on either COI or the more slowly evolving mitochondrial $16 \mathrm{~S}$ gene revealed distinctly higher interspecific values for the cryptic species complex identified (Held 2001, 2003; Leese et al. 2008b; Held and Wägele 2005; Raupach and Wägele 2006; Raupach et al. 2007.

The microsatellite results have to be interpreted in the light of the higher evolutionary rates relative to coding genes and also their fourfold greater effective population size compared to mitochondrial markers which makes them less susceptible to random genetic drift. Thus, we do not expect the microsatellite results to be identical to the mitochondrial COI data but rather complementing them.

Table 6 Comparison of different models of migration and its direction

\begin{tabular}{llllrr}
\hline & Model number & Model & HM & LBF $\left(M_{0(\mathrm{HM})}-M_{\mathrm{x}(\mathrm{HM})}\right)$ in log units & Model rank \\
\hline \multirow{3}{*}{ West to east } & $\left(M_{0}\right)$ & No gene flow & $2,618.27$ & 1.84 \\
& $\left(M_{1}\right)$ & SG-BI-MI & $2,616.43$ & 610.62 & 3 \\
\multirow{2}{*}{ East to west } & $\left(M_{2}\right)$ & SG-BI-MI(SG-MI) & $2,007.65$ & 418.97 & 1 \\
\hline
\end{tabular}

The LBF is based on the difference between the HM estimator (inferred by MIGRATE-N) of an alternative model and the null hypothesis model. Models with higher LBF are ranked above the models with low LBF. The model rank with 1 is the preferred model

$S G$ : South Georgia, BI: Bouvet Island, $M I$ : Marion Island $H M$ : harmonic mean, $L B F$ : log Bayes factor 
In contrast to the COI results the allele sharing for the microsatellite loci encompasses all three populations including South Georgia (Fig. 3; Electronic supplement 2) and is greater than expected if every island was inhabited by one reproductively isolated species. The results of MIGRATE-N support the results of the COI barcode marker that specimens belong to a single species but with limited amount of genetic flow and hence a distinct population structure. Beyond this confirmation of the mitochondrial pattern, the analysis of the microsatellite data in a statistical framework (Table 6) strongly suggests two further conclusions: (1) gene flow among populations explains the observed data significantly better than assuming no gene flow among the islands after their initial colonization and (2) the long-distance gene flow among the islands does not occur randomly but is asymmetrically biased with its majority occurring from the west toward the east. Although in principle the similarity among populations could also be caused by recent vicariance (see Avise 2000), further evidence argues against vicariance as the underlying mechanism in the case of $S$. septemcarinata. First, the islands have never been in close contact to each other but have rather different ages and geological histories. Second, molecular clock estimates utilizing the opening of the Drake Passage as a calibration point (Held 2001) support that the estimated age of the taxon $S$. septemcarinata is approximately $6 \mathrm{Ma}$. Thus, the taxon itself is older than the young volcanic islands of Bouvet (about $1 \mathrm{Ma}$, see Prestvik and Winsnes 1981) and Marion Island (about 0.45 Ma; McDougall et al. 2001), and therefore, initial founding populations must have arrived on the islands late in the species' history. But even if the molecular clock analyses had overestimated the true age of the taxon extremely, the fact that the islands arose in isolation from another and today harbor a great allelic diversity still add strong support in favor of a recurrent long-distance dispersal rather than a vicariance scenario to explain the biogeographic patterns observed in S. septemcarinata. Also, the admixture signatures (Fig. 3), the gene flow analyses (Table 6), the microsatellite allele sharing patterns (Electronic supplement 2), the large number of alleles (Table 4), and for Bouvet and Marion island also the shared COI haplotypes (Fig. 2) suggest that the initial colonization was not a singular foundation event but rather a recurrent (albeit rare or episodic) "jump dispersal" across the deep-sea barriers and even the Polar Front.

The Polar Front is a demarcation zone dividing taxa from many different evolutionary lineages into an Antarctic species and their counterparts from lower latitudes (Hunter and Halanych 2008; Krabbe et al. 2009; Lee et al. 2004; Page and Linse 2002; Thornhill et al. 2008; Wilson et al. 2009). Physiological adaptations to different temperature regimes on either side of the Polar Front, productivity differences, or simply the separating effect of the oceanographic current system (ACC) are most likely causing this zoogeographic separation. However, at least for the islands included in this study, genetic data for $S$. septemcarinata support a recent connection (albeit at low frequencies), even though few specimens could be retrieved and analyzed for Marion Island. The fact that $S$. septemcarinata is able to survive on either side of the Polar Front is perhaps less of a surprise than the evidence of migration itself across the Polar Front (north-south barrier) deduced a posteriori from the molecular data. Although we were unable to retrieve specimens for our study, the species is reported to occur on the southernmost tip of the Patagonian shelf, where it would experience conditions similar to those around Marion Island (Fig. 1). Given the strong isolation of the habitats on the one hand and the immobility of $S$. septemcarinata suggested by its brooding, ebenthic life style on the other hand, the question how $S$. septemcarinata crosses the great distances remains.

Whereas human displacement is one possible explanation (Barnes 2002), this is unlikely to apply here (uninhabited islands, very little ship traffic, no holdfasts, no small life stages to be transported in ballast water). In the absence of active means of dispersal, i.e., no free-swimming life stage, other means of effective gene flow across large distances must be present in this taxon. There are anecdotal but regular observations of animals, including benthic brooders, as passengers on rafting objects drifting in water currents (Mortensen 1933; Barnes 2002; Edgar 1987; Fell 1962; Helmuth et al. 1994; Hobday 2000; Thiel 2003; Waters 2008 and literature cited therein). At first sight, it is unexpected that $S$. septemcarinata may migrate repeatedly between the remote shallow water habitats since most serolid isopods are epibenthic and do not colonize substrata that are likely to become detached. S. septemcarinata is an exception in this respect: It has enlarged pereiopods 5-7 which it uses to climb on substrata such as large Antarctic rossellid sponges (personal observation of $\mathrm{CH}$ and $\mathrm{FL}$ during the ICEFISH 2004 expedition). While the possibility of passive rafting on sponge fragments or even entire sponges with detached anchor ice (Dayton et al. 1969) may provide a means for dispersal for the heavily glaciated Antarctic region, this is unlikely to be of importance for long-distance dispersal (McClintock et al. 2005) in the subAntarctic islands today. During the last glacial periods, ice sheets extended far to the north (see also discussion in Fraser et al. 2009) rendering the possibility of transport by anchor ice at the end of glacial periods not unlikely. However, given their much higher frequency in particular for the sub-Antarctic region, drift on large free-floating algal mats, especially those of the giant kelp Macrocystis pyrifera or the bull kelp Durvillaea antarctica, provides a more reasonable means for long-distance dispersal. After 
detachment, these algae can remain alive and even grow in the water for several months (Edgar 1987) and therefore provide a unique means for long-distance dispersal over hundreds up to several thousands of kilometers, unidirectionally in the ACC. With an average speed of approximately $40 \mathrm{~cm} \mathrm{~s}^{-1}$ in the ACC (Whitworth et al. 1982), the 2,500-km distance between South Georgia and Bouvet Island could be covered in about 70 days by rafting on freefloating kelp mats, the same holds true for the distance between Bouvet and Marion Island. The indirect approach of assessing species connectivity with microsatellites and mitochondrial gene markers showed strong population differentiation and supports a rare, possibly episodic genetic exchange predominantly from the west to the east. Further specimens from the difficult to sample Antarctic and subAntarctic islands within the ACC and from the South American shelf are needed to test the role of this current system for faunal exchange and to investigate the microevolutionary processes in particular the realized amount of gene flow and its timing in detail. Collection and analysis of a great number of rafting algal mats would provide a direct opportunity to test whether these specimens are really capable of rafting. However, as even episodic dispersal events, e.g., one rafting subpopulation every few thousand years, would suffice in theory to ensure genetic integrity over evolutionary time scales (although not differentiation). Such rare migration events would be easy to miss, thus effectively rendering the absence of direct observations insufficient for excluding rafting as an explanation for longdistance gene flow. Under these circumstances, indirect a posteriori approaches based on fast-evolving microsatellites and a mitochondrial barcoding marker are the only feasible alternative.

Whether or not the degree of recent or ongoing genetic exchange demonstrated in this paper will suffice to ensure the future maintenance of species integrity in S. septemcarinata or whether we are witnessing speciation in progress, only time will tell. It is notable, however, that there is molecular evidence for repeated long-distance dispersal over what appear to be highly effective barriers even after the original colonization in a species whose closest relatives on the Antarctic and South American shelves appear to have diverged into reproductively isolated species under conditions that seem to restrict dispersal to a lesser degree (Held 2001; Leese et al. 2008a).

Small and isolated-yet diverse?

When comparing molecular diversity estimates for the three island populations in terms of expected heterozygosity, haplotype diversity, and nucleotide diversity, it becomes obvious that the population from South Georgia shows a reduced genetic diversity in our study. This is unexpected since the characteristics of the islands (age and size, see Table 1) would suggest a comparatively large and genetically diverse population to occur around South Georgia. Interestingly, our results indicate that it is the smallest island, Bouvet Island, that has the highest genetic diversity whereas the oldest and largest island, South Georgia, has the lowest genetic diversity. Given the unexpected mobility of $S$. septemcarinata, we suggest that the high genetic diversity around Bouvet and Marion Island is likely the result of migration of specimens from as yet unsampled source populations, i.e., populations other than the one sampled from South Georgia, most likely from the Falkland Islands, the South Sandwich Islands, the South Orkney Islands, or even the South American shelf. Spatial sampling around the islands, in particular around South Georgia and Marion Island, was restricted, and hence, it cannot be neglected that deflated haplotype diversity and heterozygosity may be a result of an underlying kin structure of the population sampled. Further analyses with more samples are needed to assess demographic parameters such as population size (changes) in particular also in the context of recurrent glaciations and the impact they had on the genetic diversity of shallow water shelf fauna (Barnes and Conlan 2007; Thatje et al. 2008) in particular around South Georgia, which were much more affected compared to Bouvet or Marion Island (Clapperton et al. 1989; but see also Rosqvist et al. 1999). Since South Georgia is much older and was in close contact with the Antarctic Peninsula, it harbors a very rich and old benthic fauna (Winkler 1994 and references therein) including several larger serolid isopods which occur in great abundances in the same habitat, e.g., Serolella pagenstecheri, in contrast to Bouvet Island where other large serolids and isopods are conspicuous by their absence (Arntz et al. 2006). Hence, interspecific competition must be considered as another major aspect involved in limiting effective population size and diversity of S. septemcarinata around South Georgia but less so around Bouvet.

Islands as stepping stones to faunal exchange and biological invasions

Faunal exchange between two disjunct habitats is inversely related to the species mobility and the effectiveness of the physical barrier (e.g., the geographical distance) to surmount. Hence, highly mobile species are commonly characterized by larger, even cosmopolitan distribution ranges. However, our results strongly imply that even species without autonomous dispersal stages can migrate over much greater than expected distances and that the effectiveness of a physical barrier is not solely a function of its physical parameters but strongly depends on how organisms interact with their environment. For the shallow 
waters in the marine realm, remote islands interconnected by ocean currents in which floating objects may serve as transportation vehicles may serve as important stepping stones for faunal exchange over large distances (Nikula et al. 2010). This aspect is important in particular for the remote Southern Ocean islands and for the colonization of the Antarctic continent (Arntz et al. 2005, 2006). In view of increasing global surface temperatures and human-mediated activities, the impact of biological invasions has gained much attention recently, in particular for the Southern Ocean (Aronson et al. 2007). With changing temperatures and shifts of the Polar Frontal Zone, higher latitude marine habitats may become suitable for invading (exotic) species and algal rafting may increase. Due to their strategic position, the remote Antarctic and sub-Antarctic islands are very likely to act as the entry or exit points into and out of the Antarctic. Hence, genetic analyses of population structure of both indigenous and also invading species provides an important aspect to understand and predict the impacts of these influences.

\section{Conclusions}

Genetic a posteriori estimates of species integrity are important to gain a deeper understanding of the realized distribution ranges of marine species and the frequency of gene flow among remote populations. In this study, we present molecular evidence that even in the absence of dispersal stages, long-distance dispersal among strongly isolated islands has not been a singular event in the history of the marine benthic isopod S. septemcarinata but has occurred repeatedly in the period after initial colonization and maybe continues to occur today. Estimates of gene flow not only indicate that the Polar Front is less a barrier to gene flow in this species than expected but also indicate that the long-distance dispersal events that occur are rare or episodic. The gene flow is directional rather than random with its majority being directed from the west to the east. Based on the congruence of the preferred direction of gene flow and the flow direction of the Antarctic Circumpolar Current, we propose passive rafting on floating substrata even across the Polar Front as one explanation for longdistance dispersal in this benthic brooding isopod.

Acknowledgments $\mathrm{FL}$ and $\mathrm{CH}$ are grateful to Wolfgang Wägele and Ralph Tollrian for helpful discussions and support and to Andrea Eschbach and Annegret Müller for technical assistance. We thank Martin Thiel, Chester J. Sands, and two anonymous reviewers for helpful comments on the manuscript and Peter Beerli for help with MIGRATE-N. This work was supported by Deutsche Forschungsgemeinschaft grant HE-3391/3 to CH and MA3684 to FL and Christoph Mayer, and National Science Foundation grant OPP-0132032 to H.W. Detrich III. This is publication number 23 from the ICEFISH Cruise of 2004.

\section{References}

Adams J (2009) Species richness: patterns in the diversity of life. Springer, Berlin

Arntz WE, Thatje S, Gerdes D et al (2005) The Antarctic-Magellan connection: macrobenthos ecology on the shelf and upper slope, a progress report. Sci Mar 69:237-269

Arntz WE, Thatje S, Linse K et al (2006) Missing link in the Southern Ocean: sampling the marine benthic fauna of remote Bouvet Island. Polar Biol 29:83-96

Aronson RB, Thatje S, Clarke A et al (2007) Climate change and invasibility of the Antarctic benthos. Annu Rev Ecol Syst 38:129-154

Avise JC (2000) Phylogeography. The history and formation of species. Harvard University Press, Cambridge

Avise JC (2004) Molecular markers, natural history, and evolution. Sinauer Associates, Sunderland

Barnes DK, Conlan KE (2007) Disturbance, colonization and development of Antarctic benthic communities. Philos Trans R Soc Lond B Biol Sci 362:11-38

Barnes DK (2002) Biodiversity: invasions by marine life on plastic debris. Nature 416:808-809

Beerli P, Palczewski M (2010) Unified framework to evaluate panmixia and migration direction among multiple sampling locations. Genetics (in press)

Bohonak AJ (1999) Dispersal, gene flow, and population structure. Q Rev Biol 74:21-43

Brandt A, Gooday AJ, Brandao SN et al (2007) First insights into the biodiversity and biogeography of the Southern Ocean deep sea. Nature 447:307-311

Brandt A (1991) Colonization of the Antarctic shelf by the Isopoda (Crustacea, Malacostraca). Ber Polarforsch 98:1-240

Burg TM, Croxall JP (2004) Global population structure and taxonomy of the wandering albatross species complex. Mol Ecol 13:2345-2355

Clapperton CM, Sugden DE, Birnie J, Wilson MJ (1989) Late-glacial and Holocene glacier fluctuations and environmental change on South Georgia, Southern Ocean. Quat Res 31:210-228

Coyne JA, Orr HA (2004) Speciation. Sinauer Associates, Sunderland

Dayton PK, Robilliard G, DeVries AL (1969) Anchor ice formation in McMurdo Sound, Antarctica, and its biological effects. Science 163:273-274

Edgar GJ (1987) Dispersal of faunal and floral propagules associated with drifting Macrocystis pyrifera plants. Mar Biol 95:599-610

Fell HB (1962) West-wind-drift dispersal of echinoderms in the southern hemisphere. Nature 4817:759-761

Féral JP (2002) How useful are the genetic markers in attempts to understand and manage marine biodiversity? J Exp Mar Bio Ecol 268:121-145

Folmer O, Black M, Hoeh W et al (1994) DNA primers for amplification of mitochondrial cytochrome c oxidase subunit I from diverse metazoan invertebrates. Mol Mar Biol Biotechnol 3:294-299

Fraser CI, Nikula R, Spencer HG, Waters JM (2009) Kelp genes reveal effects of subantarctic sea ice during the Last Glacial Maximum. Proc Natl Acad Sci USA 106:3249-3253

Gouretski VV, Koltermann KP (2004) Berichte des Bundesamtes für Seeschifffahrt und Hydrographie 35

Graves JE (1998) Molecular insights into the population structures of fishes with circumglobal distributions. J Hered 89:427-437

Gutt J, Sirenko BI, Smirnov IS, Arntz WE (2004) How many macrozoobenthic species might inhabit the Antarctic shelf? Antarct Sci 16:11-16

Held C (2003) Molecular evidence for cryptic speciation within the widespread Antarctic crustacean Ceratoserolis trilobitoides 
(Crustacea, Isopoda). In: Huiskes AH, Gieskes WW, Rozema J, Schorno RM, van der Vies SM, Wolff WJ (eds) Antarctic biology in a global context. Backhuys, Leiden, pp 135-139

Held C, Leese F (2007) The utility of fast evolving molecular markers for studying speciation in the Antarctic benthos. Polar Biol 30:513-521

Held C, Wägele J-W (2005) Cryptic speciation in the giant Antarctic isopod Glyptonotus antarcticus (Isopoda: Valvifera: Chaetiliidae). Sci Mar 69:175-181

Held C (2001) No evidence for slow-down of molecular substitution rates at subzero temperatures in Antarctic serolid isopods (Crustacea, Isopoda, Serolidae). Polar Biol 24:497-501

Hellberg ME, Burton RS, Neigel JE, Palumbi SR (2002) Genetic assessment of connectivity among marine populations. Bull Mar Sci 70:273-290

Helmuth B, Veit RR, Holberton R (1994) Long-distance dispersal of a subantarctic brooding bivalve (Gaimardia trapesina) by kelprafting. Mar Biol 120:421-426

Hobday AJ (2000) Persistence and transport of fauna on drifting kelp (Macrocystis pyrifera (L.) C. Agardh) rafts in the Southern California Bight. J Exp Mar Bio Ecol 253:75-96

Hudson RR, Slatkin M, Maddison WP (1992) Estimation of levels of gene flow from DNA sequence data. Genetics 132:583-589

Hunter RL, Halanych KM (2008) Evaluating connectivity in the brooding brittle star Astrotoma agassizii across the drake passage in the Southern Ocean. J Hered 99:137-148

Jarman SN, Elliott NG, Nicol S, McMinn A (2002) Genetic differentiation in the Antarctic coastal krill Euphausia crystallorophias. Heredity 88:280-287

Krabbe K, Leese F, Mayer C et al (2009) Cryptic mitochondrial lineages in the widespread pycnogonid Colossendeis megalonyx Hoek, 1881 from Antarctic and Subantarctic waters. Polar Biol 33:281-292

Lee YH, Song M, Lee S et al (2004) Molecular phylogeny and divergence time of the Antarctic sea urchin (Sterechinus neumayeri) in relation to the South American sea urchins. Antarct Sci 16:29-36

Leese F, Held C (2008) Identification and characterization of microsatellites from the Antarctic isopod Ceratoserolis trilobitoidesnuclear evidence for cryptic species. Conserv Genet 9:13691372

Leese F, Kop A, Wägele JW, Held C (2008a) Cryptic speciation in a benthic isopod from Patagonian and Falkland Island waters and the impact of glaciations on its population structure. Frontiers Zool 5:19

Leese F, Kop A, Agrawal S, Held C (2008b) Isolation and characterization of microsatellite markers from the marine isopods Serolis paradoxa and Septemserolis septemcarinata (Crustacea: Peracarida). Mol Ecol Res 8:818-821

McClintock JB, Amsler CD, Baker BJ, van Soest RWM (2005) Ecology of Antarctic marine sponges: an overview. Integr Comp Biol 45:359-368

McDougall I, Verwoerd W, Chevallier L (2001) K-Ar geochronology of Marion Island, Southern Ocean. Geological Magazine 1:1-17

McQuinn IH (1997) Metapopulations and the Atlantic herring. Rev Fish Biol Fish 7:297-329

Meirmans PG (2006) Using the AMOVA framework to estimate a standardized genetic differentiation measure. Evolution 60:2399 2402

Mortensen T (1933) The echinoderms of St Helena (other than crinoids). Vid Medd dansk naturh For 93:401-472

Neigel JE (1997) A comparison of alternative strategies for estimating gene flow from genetic markers. Annu Rev Ecol Syst 28:105-128

Nikula R, Fraser CI, Spencer HG, Waters JM (2010) Circumpolar dispersal by rafting in two subantarctic kelp-dwelling crustaceans. Mar Ecol Prog Ser (in press)
O'Hara T (1998) Origin of Macquarie Island echinoderms. Polar Biol 20:143-151

Orsi AH, Whitworth T, Nowlin WD (1995) On the meridional extent and fronts of the Antarctic Circumpolar Current. Deep-Sea Res (1 Oceanogr Res Pap) 42:641-673

Page TJ, Linse K (2002) More evidence of speciation and dispersal across the Antarctic Polar Front through molecular systematics of Southern Ocean Limatula (Bivalvia: Limidae). Polar Biol $25: 818-826$

Pawlowski J, Fahrni J, Lecroq B et al (2007) Bipolar gene flow in deep-sea benthic foraminifera. Mol Ecol 16:4089-4096

Prestvik T, Winsnes TS (1981) Geology of Bouvetoya, South Atlantik. Skr Norsk Polarins 175:41-68

Raupach MJ, Malyutina M, Brandt A, Waegele JW (2007) Molecular data reveal a highly diverse species flock within the munnoposid deep-sea isopod Betamorpha fusiformis (Barnard, 1920) (Crustacea: Isopoda: Asellota) in the Southern Ocean. Deep-Sea Res (2 Trop Stud Oceanogr) 54:1820-1830

Raupach MJ, Wägele JW (2006) Distinguishing cryptic species in Antarctic Asellota (Crustacea: Isopoda) - a preliminary study of mitochondrial DNA in Acanthaspidia drygalskii. Antarc Sci 18:191-198

Rosqvist GC, Rietti-Shati M, Shemesh A (1999) Late glacial to middle Holocene climatic record of lacustrine biogenic silica oxygen isotopes from a Southern Ocean island. Geology 27:967-970

Slatkin M (1987) Gene flow and the geographic structure of natural populations. Science 236:787-792

Stewart RH (2007) Introduction to physical oceanography. Texas A \& M University, College Station

Swearer SE, Caselle JE, Lea DW, Warner RR (1999) Larval retention and recruitment in an island population of a coral-reef fish. Nature 402:799-802

Thatje S, Hillenbrand C, Mackensen A, Larter R (2008) Life hung by a thread: endurance of Antarctic fauna in glacial periods. Ecology 89:682-692

Thiel M (2003) Rafting of benthic macrofauna: important factors determining the temporal succession of the assemblage on detached macroalgae. Hydrobiol 503:39-57

Thiel M, Haye PA (2006) The ecology of rafting in the marine environment. III. Biogeographical and evolutionary consequences. Oceanogr Mar Biol Annu Rev 44:323-429

Thornhill DJ, Mahon AR, Norenburg JL, Halanych KM (2008) Openocean barriers to dispersal: a test case with the Antarctic Polar Front and the ribbon worm Parborlasia corrugatus (Nemertea: Lineidae). Mol Ecol 17:5104-5117

Waters JM (2008) Driven by the West Wind Drift? A synthesis of southern temperate marine biogeography, with new directions for dispersalism. J Biogeogr 35:417-427

Waters JM, Roy MS (2004) Out of Africa: the slow train to Australasia. Syst Biol 53:18-24

Wägele J (1994) Notes on Antarctic and South American Serolidae (Crustacea, Isopoda) with remarks on the phylogenetic biogeography and a description of new genera. Zool Jahrb Abt Syst Ökol Geogr Tiere 121:3-69

Weir BS, Cockerham CC (1984) Estimating F-statistics for the analysis of population structure. Evolution 38:1358-1370

Whitworth T, Nowlin WD, Worley SJ (1982) The net transport of the Antarctic Circumpolar Current through Drake Passage. Journal of Physiological Oceanography 12:960-971

Wilson NG, Schrödl M, Halanych KM (2009) Ocean barriers and glaciation: evidence for explosive radiation of mitochondrial lineages in the Antarctic sea slug Doris kerguelenensis (Mollusca, Nudibranchia). Mol Ecol 18:965-984

Winkler H (1994) Characterization of the Scotia Arc isopod fauna (Crustacea, Malacostraca) from a biogeographical point of view: a multivariate approach. Ber Polarforsch 139:1-196 